\title{
Damage to lemon tree caused by simulated drift of herbicides
}

\author{
Danos ao limoeiro causados por deriva simulada de herbicidas
}

\section{Leandro Galon ${ }^{1 *}$, Clevison Luis Giacobbo ${ }^{2}$, André Ricardo Zeist ${ }^{3}$, Marlon Ouriques Bastiani ${ }^{4}$, Doralice Lobato de Oliveira Fischer ${ }^{5}$, Ketholly Nayara Henrique Domingos ${ }^{2}$, Cesar Tiago Forte ${ }^{6}$}

\author{
${ }^{1}$ Universidade Federal da Fronteira Sul, Erechim, RS, Brasil. *Author for correspondence: leandro.galon@uffs.edu.br \\ ${ }^{2}$ Universidade Federal da Fronteira Sul, Chapecó, SC, Brasil. \\ ${ }^{3}$ Universidade do Oeste Paulista, Presidente Prudente, SP, Brasil. \\ ${ }^{4}$ Três Tentos Agroindustrial S.A., Dom Pedrito, RS, Brasil. \\ ${ }^{5}$ Instituto Federal do Sul, Pelotas, RS, Brasil. \\ ${ }^{6}$ Universidade Federal de Santa Maria, Santa Maria, RS, Brasil.
}

Submission: 26/02/2019 / Acceptance: 22/06/2020

\begin{abstract}
The use of herbicides, in particular clomazone and glyphosate, applied in isolation or in a tank mix, is very common in rice, soybeans, corn and sugarcane fields and the drift of these herbicides can cause damage in sensitive species grown nearby. The purpose of this work was to evaluate the effects of the simulated drift of clomazone and glyphosate applied in an isolated way or mixed in a spray on lemon tree plants. The experiment was installed in a greenhouse in pots with a capacity of $15 \mathrm{~L}$ containing sieved soil and an experimental design of randomized blocks was adopted, arranged in a $3 \times 5$ factorial scheme, with four replications. Plants with two years of development were used. The treatments tested were, clomazone, glyphosate and both mixed, and the decreasing doses of the recommended commercial product: 100,75 , 50,25 and $0 \%$ to simulate herbicide drift. Was evaluated variables, phytotoxicity at $14,28,46$ and 100 days after application of treatments; plant height, crown volume, the trunk diameter of the rootstock, trunk diameter of the graft and trunk diameter at the grafting point at 0 and 100 days after application of treatments; and liquid assimilation of $\mathrm{CO}_{2}$ at 10 and 60 days after application of treatments. Among the tested herbicides, the one that presented the highest phytotoxicity and the lowest liquid assimilation of $\mathrm{CO}_{2}$ in lemon tree plants was the glyphosate + clomazone mixture. Increases in trunk diameter of the rootstock, grafting point, graft and crown volume did not show significant effects with simulated drift. The plant height presented a greater reduction with the increase of the herbicide doses, mainly glyphosate. That there are considerable losses in lemon tree plants when herbicide drift occurs, mainly by glyphosate and its mixture with clomazone.
\end{abstract}

KEYWORDS: Citrus limonium, glyphosate, clomazone.

\section{RESUMO}

O uso de herbicidas, em especial o clomazone e o glyphosate, aplicados de modo isolado ou em mistura em tanque, é muito comum em lavouras de arroz, soja, milho e cana-de-açúcar e a deriva desses herbicidas pode ocasionar danos em espécies sensíveis cultivadas próximas. Objetivou-se com o trabalho avaliar os efeitos da deriva simulada de clomazone e glyphosate aplicados de modo isolado ou em mistura em tanque do pulverizador sobre plantas de limoeiro. $O$ experimento foi instalado em casa de vegetação em vasos com capacidade de $15 \mathrm{~L}$ contendo solo peneirado. Adotou-se delineamento experimental de blocos casualizados, arranjado em esquema fatorial $3 \times 5$, com quatro repetições. Utilizou-se plantas com dois anos de desenvolvimento. No fator $A$ foram alocados os herbicidas; clomazone, glyphosate e a mistura de ambos em tanque, e no $\mathrm{B}$ as doses decrescentes do produto comercial recomendado: 100, 75, 50, 25 e $0 \%$ para simular a deriva dos herbicidas (Clomazone $^{\circledR}$, Roundup Original $^{\circledR}$ e a mistura de ambos). As variáveis avaliadas foram: fitotoxicidade aos $14,28,46$ e 100 dias após a aplicação dos tratamentos; altura de planta, volume de copa, diâmetro de tronco do portaenxerto, diâmetro de tronco do enxerto e diâmetro de tronco no ponto de enxertia aos 0 e 100 dias após aplicação dos tratamentos; e aos 10 e 60 dias após aplicação dos tratamentos, assimilação líquida de $\mathrm{CO}_{2}$. Dentre os herbicidas testados o que apresentou maior fitotoxicidade e menor assimilação líquida de $\mathrm{CO}_{2}$ nas plantas de limoeiro foi a mistura de glyphosate + clomazone, principalmente nas primeiras avaliações. Os incrementos do diâmetro de tronco do porta-enxerto, do ponto de enxertia e do enxerto e volume de copa não apresentaram efeitos expressivos com a deriva simulada dos herbicidas. A altura das plantas apresentou maior redução com 0 aumento das doses dos herbicidas, principalmente do 
glyphosate. Conclui-se que, há prejuízos consideráveis em plantas de limoeiro quando da ocorrência de deriva de herbicidas, principalmente pelo glyphosate e a mistura desse com clomazone.

PALAVRAS-CHAVE: Citrus limonium, glyphosate, clomazone.

\section{INTRODUCTION}

Brazil stands out in the fruits production, among them citrus, mainly in small properties. The lemon tree among the citrus fruits has a harvested area of 47,279 ha and an average yield of $26,700 \mathrm{~kg} \mathrm{ha}^{-1}$ (IBGE 2019). In many regions of Brazil the cultivation of fruitful trees is a secondary property activity, as occurs in the West Frontier of Rio Grande do Sul, RS, which has the predominance of irrigated rice crops (GIACOBBO et al. 2018). To control the pests in rice, farmers have often applied agrochemicals through aircrafts, including herbicides whose drift to orchards reduce fruit productivity. It is worth mentioning that in the last agricultural crops many grapes, olive and other fruits producers in the state of Rio Grande do Sul have reported high losses due to the herbicide drift, mainly hormonal, that are applied to weed control in crops such as soy, corn and rice (RIGOLI et al. 2008, GIACOBBO et al. 2018).

During the rice cycle, at least three herbicides applications with different mechanisms of action (MOHAPATRA et al. 2017). In addition, in many situations, rice grower mix clomazone + glyphosate and, when the application occurs inadequately, losses to fruit growers are even bigger (FORESTI et al. 2015, GIACOBBO et al. 2018). The role of herbicides in agricultural environments will continue to be fundamental, but it's necessary more in-depth study about their effects, especially when there is a drift of these products in the plants community, water and arthropods (EGAN et al. 2014).

On the West Frontier of Rio Grande do Sul, aircraft are commonly used to apply herbicides. The use of aircraft and herbicides with different action mechanisms increases the potential of drift problems to crops with secondary interests when applied inappropriately. The drift corresponds to dragging by the wind or even by volatilization of small droplets of the herbicide syrup pulverized, being influenced by the physicochemical characteristics of the herbicide, as well as its technology application and meteorological conditions at the time of sprinkling of the products (COSTA et al. 2007, CUNHA 2008, OLIVEIRA et al. 2013).

In a study by GIACOBBO et al. (2018), in West Frontier of Rio Grande do Sul, under the drift product effect applied to rice cultivation, on grapevine crop, these authors verified that the main herbicides that cause damages in fruitful plants are clomazone and glyphosate and mainly, by the mixture of clomazone + glyphosate. Clomazone belongs to chemical group of isoxazolidinones, which inhibits the biosynthesis of carotenoids, is absorbed by the apical meristem of the plant, and its translocation occurs through the xylem (phloem), following the transpiration flux, the injuries symptoms are manifested in the most new ones (DRIVER et al. 2020). The clomazone presents potential to cause drift when applied in pre-emergence without incorporation to the soil (GIACOBBO et al. 2018). In rice crops of RS this herbicide is applied in most situations right after the emergence of rice and without incorporation into the soil increasing the possibilities of drift. TIMOSSI \& ALVES (2001) report that the negative effects of clomazone on orange fruit at the stage of fruit development resulted in chlorotic and necrotic spots on the fruit peel and caused the mortality of branches that were in vegetative growth.

Glyphosate is classified as a non-selective, systemic herbicide with a broad spectrum of action for weeds, being predominantly absorbed by the chlorophyll region of the plants (leaves and green tissues), translocated mainly by the phloem to the meristematic tissues and belongs to the chemical group of the substituted glycines (DUKE 2018).

The use of glyphosate occurs in vegetation desiccation before the rice sowing or when the crop is at the needle point, having a broad spectrum of action and being systemic the rice farmers have reduced the volume of syrup to optimize the work in the applications, which causes serious problems of herbicide drift to non-target areas (RODRIGUES et al. 2015).

WAGNER JR. et al. (2008) working with glyphosate, simulating drift in passion fruit, observed that in spite of causing damage to plants, hindering growth, root dry mass and leaf area, did not affect the stem diameter and the leaves number of young passion fruit plants. According to HEMPHILL \& MONTGOMERY (1981), damages caused by herbicide drift is recognized as a problem in many areas. Therefore, it is important to mention that the observed symptoms in the plants caused by drift are affected by factors such as species, development stage, climatic conditions, action mechanism, herbicide doses (FERREIRA et al. 2006) and also with the technology application utilized. Results of decreased leaf area, chlorophyll content, leaf dry mass and stem were described by FORESTI et al. (2015). GRAVENA et al. (2012) though, verified that orange trees Valencia grafted with 'Cravo' lemon and 'Swingle' citrumelo are tolerant to doses up to 720 $\mathrm{g} \mathrm{ha}^{-1}$ of glyphosate acid equivalent and recover after 6 to 12 months. 
It is necessary to emphasize that, the peaks of herbicide applications occur in the months of September and October, coinciding with the flowering and the formation of citrus fruits. This fact may jeopardize the fruit production in the agricultural year of occurrence and /or compromise the useful orchard life. The purpose of this work was to evaluate the effects of the simulated drift of clomazone and glyphosate applied in an isolated way or in a mixture tank on lemon plants.

\section{MATERIAL AND METHODS}

The experiment was conducted in a greenhouse in the experimental area of Universidade Federal do Pampa, Itaqui, RS, Brazil (29 ${ }^{\circ} 09^{\prime} 34.2$ "S, $56^{\circ} 33^{\prime} 15.9 " \mathrm{~W}$, altitude of $57 \mathrm{~m}$ ) in the agricultural year $2011 / 12$ and installed in plastic pots with capacity for $15 \mathrm{~L}$ containing soil classified as Plinthudult and corrected for fertility (SANTOS et al. 2013). The chemical and physical characteristics of the soil were: $\mathrm{pH}$ in water of 4.8; $\mathrm{MO}=4.7 \mathrm{dag} / \mathrm{kg} ; \mathrm{P}=6.8 \mathrm{mg} / \mathrm{dm}^{3} ; \mathrm{K}=48 \mathrm{mg} / \mathrm{dm}^{3} ; \mathrm{Al}^{3+}=0.5 \mathrm{cmolc} / \mathrm{dm}^{3} ; \mathrm{Ca}^{2+}=4.76 \mathrm{cmolc} / \mathrm{dm}^{3} ; \mathrm{Mg}^{2+}=1.03$ cmolc $/ \mathrm{dm}^{3} ; \mathrm{CTC}(\mathrm{t})=6.4 \mathrm{cmolc} / \mathrm{dm}^{3} ; \mathrm{CTC}(\mathrm{T})=15.6 \mathrm{cmolc} / \mathrm{dm}^{3} ; \mathrm{H}+\mathrm{Al}=9.7 \mathrm{cmolc} / \mathrm{dm}^{3} ; \mathrm{SB}=60.59 \mathrm{cmolc} / \mathrm{dm}^{3}$; $\mathrm{V}=38 \%$; e Clay $=20 \%$.

The utilized lemon crop was BRS-Fino, grafted on the rootstock Poncirus trifoliata. The trial consisted of forty-five lemon tree plants at the age of two years. It was installed in an experimental block design with random treatments, arranged in a $3 \times 5$ factorial scheme, with four replications. In factor $A$ the allocated herbicides were; clomazone, glyphosate and the mixture of both in tank (clomazone + glyphosate), and in B the decreasing doses of the recommended commercial product: $100 \%, 75 \%, 50 \%, 25 \%$ and $0 \%$ to simulate herbicide drift (Gamit ${ }^{\circledR}$, Roundup Original ${ }^{\circledR}$ and the mixture of both). The recommended doses (100\%) of clomazone and glyphosate for weed control in irrigated rice are 0.8 and $3.0 \mathrm{~L} \mathrm{ha}^{-1}$ of commercial product, respectively, or 500 and $1440 \mathrm{~g} \mathrm{ha}^{-1}$ of active ingredient (RODRIGUES \& ALMEIDA 2018). The Herbicides were applied on 11/30/2011 with a $\mathrm{CO}_{2}$-pressurized backpack sprayer coupled to two spray nozzles tips, model DG 110.02, spaced at $0.5 \mathrm{~m}$, at a height of $0.5 \mathrm{~m}$ from the target, which sprinkled $150 \mathrm{~L} \mathrm{ha}^{-1}$ of spray volume. Environmental conditions at the application were: high insolation, temperature of $25{ }^{\circ} \mathrm{C}$, air humidity of about $68 \%$, dry soil and wind speed about $3 \mathrm{~m} \mathrm{~s}^{-1}$.

During the experimental period, the seedlings were irrigated periodically and all necessary phytosanitary measures were taken to ensure the normal development of the plants, including the area being kept free of weeds, to avoid possible competition and mask the results.

At 14, 28, 46 and 100 days after application of the treatments (DAT), herbicide phytotoxicity were evaluated on lemon tree plants using a visual method. For this, two trained reviewers assigned percentage marks from 0 to $100 \%$, which $0 \%$ corresponds to non phytotoxicity and $100 \%$ complete death of plants (SBCPD 1995).

The analyzed variables were height of plants, with the aid of a graduated ruler measuring from the base of the plant until the end of the growth meristem; volume of the crown calculated by the height, thickness and width of the crown (GIACOBBO et al. 2018). On the other hand, the stem diameter at the point of grafting, stem diameter of the rootstock and stem diameter of the graft variables were measured with a digital caliper, measuring at the exact point where the grafting was performed (diameter of the grafting), $10 \mathrm{~cm}$ above the grafting point (stem diameter of the rootstock), and $10 \mathrm{~cm}$ below of the grafting point, these evaluations were carried out before the drift simulation (herbicide application) and 100 DAT to be able to establish the percentage of increase in relation to the different treatments. On this way, was established the increase of the height of the plants, increase of the crown volume, increase of the trunk diameter of the rootstock, increase of the trunk diameter at the grafting point and increment of graft trunk diameter.

It was also evaluated liquid assimilation of $\mathrm{CO}_{2}$ or photosynthetic yield $\left(\mathrm{A}-\mu \mathrm{mol} \mathrm{m} \mathrm{m}^{-2} \mathrm{~s}-1\right)$ at 10 and 60 DAT with an infrared gas analyzer (IRGA), ADC brand, LCA PRO model (Analytical Development Co. Ltd, Hoddesdon, UK), each block being evaluated under natural light in one day, between eight and ten o'clock in the morning under natural light, so that the ambient conditions were maintained homogeneous during the analyzes. Three samples of fully expanded leaves, located in the upper middle third, were evaluated from each plot.

The data were submitted to analysis of variance by the $\mathrm{F}$ test and, when significant, we proceeded to regression analysis and means comparison test for qualitative comparisons. All tests were performed at $\mathrm{p} \leq 0.05$.

\section{RESULTS AND DISCUSSION}

The model that set at 14 and 28 DAT was linear, that is, for each herbicide dose addition, the phytotoxicity of the lemon tree plants was linearly increased (Figures 1A and 1B). At 46 and 100 DAT, 
adjustment for nonlinear or hyperbolic model occurred, where the increase of injury was linear up to the subdose of $25 \%$ in relation to that recommended for all the herbicides and afterwards occurred the symptoms establishment, except at 46 DAT for the mixture of clomazone + glyphosate that continued to increase the injuries (Figures 1C and 1D).
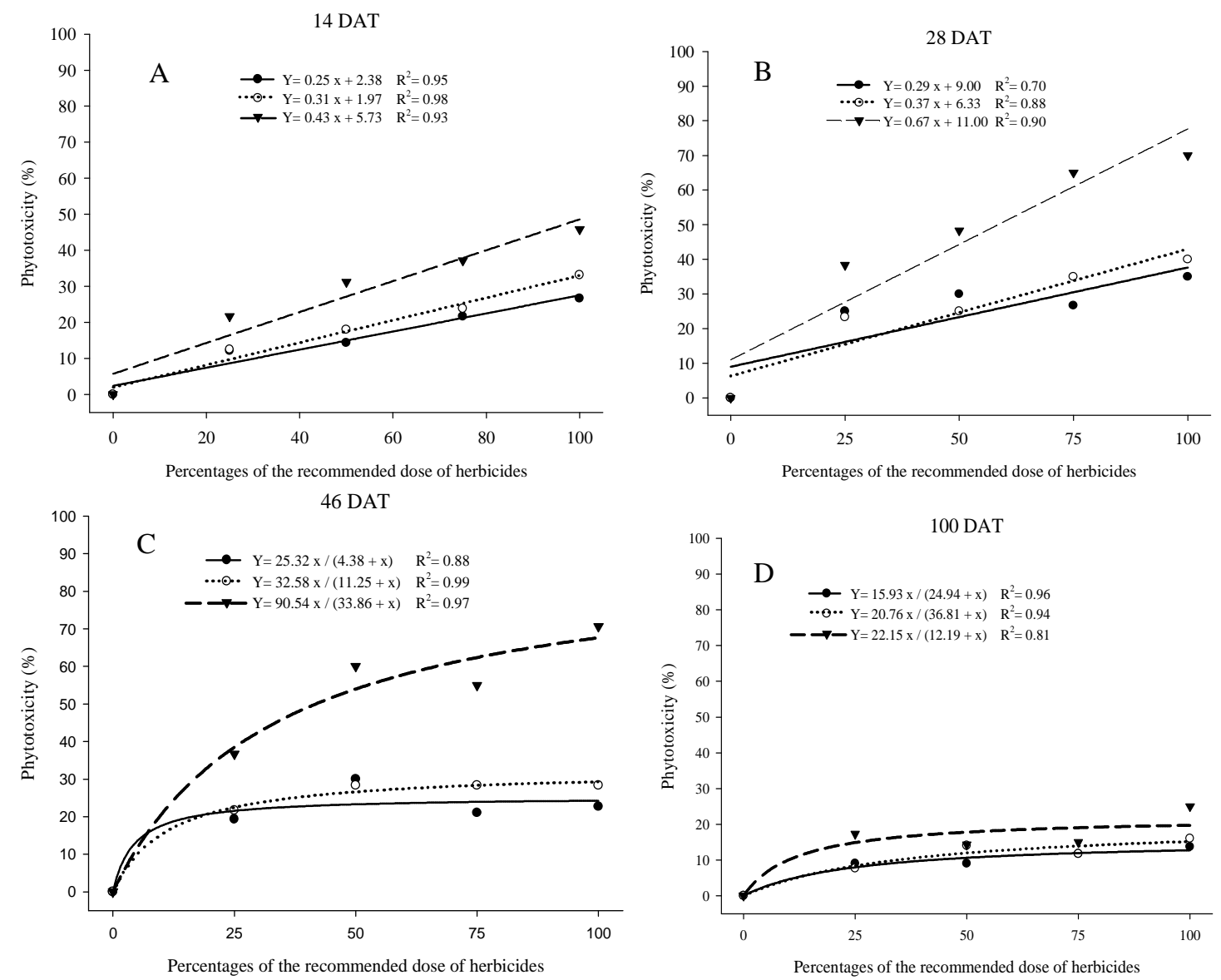

Figure 1. Phytotoxicity (\%) in lemon plants at 14 (A), 28 (B), 46 (C) and 100 (D) days after treatments application (DAT) when treated with the percentage of the herbicide recommended dose of clomazone $(\bullet)$, glyphosate $(\circ)$ and the clomazone + glyphosate $(\boldsymbol{\nabla})$ tank mix.

It was observed that the new leaves sprouted withered, shriveled and with visible symptoms of phytotoxicity caused by herbicides. Leaf depigmentation (albinism) occurred for the application of clomazone, chlorosis or necrosis for glyphosate and depigmentation, chlorosis and necrosis for the mixture of both. In addition, a fall in the basal leaves was observed for all treatments. These symptoms are due to the mechanisms of action of the herbicide referents. Clomazone belongs to isoxazolidinon chemical group, and acts inhibits carotenoid biosynthesis, with its symptoms usually manifesting in younger organs (FOROUZESH et al. 2015); and glyphosate as it is predominantly absorbed by the chlorophyll region of plants and inhibits the EPSPS enzyme (5-enolpyruvate-chiquimate-3-phosphate synthase) from the metabolic pathway of chiquimic acid, causes damage to all plant parts and mainly to the greenest (OLIVEIRA JR. 2011). For fruit trees, in general, applications of glyphosate in foliage are more harmful to young plants and tissues, than to mature plants (FORESTI et al. 2015).

It should be noted that the drift effect caused by the clomazone + glyphosate tank mixture was significantly higher on the lemon tree in at all seasons, with higher phytotoxicity symptoms on the plants if compared with the herbicides applied individually (Figures 1A, 1B, 1C and 1D). Besides that, herbicide mixing in tanks enhances drift capacity, as was found when glyphosate was mixed with 2,4-D by GANDOLFO et al. (2012). Similar results to those found in the present study were verified with grapevine cultivation, which glyphosate and the clomazone + glyphosate tank mix showed the highest phytotoxicity (GIACOBBO et al. 2018). The same authors also verified that all treatments involving tested herbicides (clomazone, glyphosate and clomazone + glyphosate), individually or in combination, with increased dose to grapevine plants paralyzed the growth in height, crown volume and trunk diameter in the grafting point. 
Clomazone and glyphosate have some characteristics to increase the potential for drift and damage. Both have dissipation capacity with emphasis on clomazone (BANDANA et al. 2015, CABRAL et al. 2017, RIBEIRO et al. 2020). In addition, the persistence of clomazone and glyphosate in the soil varies substantially. Clomazone is classified as a non-persistent pesticide, however, its persistence in the soil can be longer than 150 days (RIBEIRO et al. 2020). The form of clomazone dissipation via water solubility and volatilization, makes its residue prone to promote toxic visual effect in non-target plants (SILVA et al. 2018). In the case of glyphosate, it is easily absorbed by the foliage and due to its high potential for translocation via phloem, the damage is enhanced (BANDANA et al. 2015).

Many agricultural crops of interest are being genetically modified to induce resistance to many herbicides, such as glyphosate, ammonium glufosinate, 2,4-D, dicamba, among others. Thus, losses to nontarget crops may be even greater when drift occurs (EGAN et al. 2014). It is emphasized that the resistance of agricultural crops to hormonal herbicides such as 2,4-D and dicamba if it occurs in susceptible crops may have more deleterious effects than those observed for glyphosate, clomazone and both mixed in tank on grapevine cultivation (GIACOBBO et al. 2018), or in the case of lemon tree plant in the present study. On coffee plants, the 2,4-D herbicide drift simulation was not detrimental to productivity (RONCHI et al. 2005), even so the care with these products should be reinforced, especially those with high volatility in the environment.

At 14 DAT, it was observed that the clomazone + glyphosate mixture, even in sub doses, caused the greatest damages to the plants, and at the recommended dose (100\%) provided about $40 \%$ of phytotoxicity (Figure 1A and Table 1). At the same time when evaluating herbicides applied in isolation, it can be noticed that glyphosate caused the greatest phytotoxic effects on plants and clomazone caused less damage. The glyphosate application in the orange tree stalk did not present a phytotoxic effect for the plants, but, when the use was on the leaves, there was damage to the fruit at doses of $360 \mathrm{~g} \mathrm{ha}^{-1}$ of ea, and the main effects were observed in growth meristem on plants (GRAVENA et al. 2012).

Table 1. Phytotoxicity (\%) in lemon tree plants at $14,28,46$ and 100 days after treatments application (DAT), due to the herbicide application and the percentage of the recommended dose for the weeds control in irrigated rice.

\begin{tabular}{|c|c|c|c|c|c|}
\hline \multirow{3}{*}{ Herbicides } & \multicolumn{5}{|c|}{ Percentages of the recommended dose of herbicides } \\
\hline & $0 \%$ & $25 \%$ & $50 \%$ & $75 \%$ & $100 \%$ \\
\hline & \multicolumn{5}{|c|}{14 DAT } \\
\hline Člomazone & $0 a^{1}$ & $12.2 \mathrm{~b}$ & $14.3 \mathrm{~b}$ & $21.7 \mathrm{~b}$ & $26.7 \mathrm{c}$ \\
\hline Glyphosate & $0 \mathrm{a}$ & $12.8 \mathrm{~b}$ & $18.0 \mathrm{~b}$ & $23.8 \mathrm{~b}$ & $33.2 \mathrm{~b}$ \\
\hline Clomazone + glyphosate & $0 \mathrm{a}$ & $21.7 \mathrm{a}$ & $31.2 \mathrm{a}$ & $37.2 \mathrm{a}$ & $45.8 \mathrm{a}$ \\
\hline $\bar{c} \overline{(\%)}$ & \multicolumn{5}{|c|}{10.5} \\
\hline Herbicides & \multicolumn{5}{|c|}{$28 \mathrm{DAT}$} \\
\hline Clomazone & $0 \bar{a}$ & $25.0 \mathrm{a}$ & $30.0 \mathrm{~b}$ & $26.7 \mathrm{~b}$ & $35.0 \mathrm{~b}$ \\
\hline Glyphosate & $0 \mathrm{a}$ & $23.3 \mathrm{a}$ & $25.0 \mathrm{~b}$ & $35.0 \mathrm{~b}$ & $40.0 \mathrm{~b}$ \\
\hline Clomazone + glyphosate & $0 \mathrm{a}$ & $32.5 \mathrm{a}$ & $48.3 \mathrm{a}$ & $65.0 \mathrm{a}$ & $70.0 \mathrm{a}$ \\
\hline $\bar{c} \bar{c}(\%)$ & \multicolumn{5}{|c|}{17.3} \\
\hline Herbicides & \multicolumn{5}{|c|}{$46 \overline{D A T}$} \\
\hline Clomazone & $0 \mathrm{a}$ & $19.3 \mathrm{a}$ & $30.0 \mathrm{~b}$ & $21.0 \mathrm{~b}$ & $22.7 \mathrm{~b}$ \\
\hline Glyphosate & $0 \mathrm{a}$ & $21.7 \mathrm{a}$ & $28.3 \mathrm{~b}$ & $28.0 \mathrm{~b}$ & $28.3 \mathrm{~b}$ \\
\hline Clomazone + glyphosate & $0 \mathrm{a}$ & $30.0 \mathrm{a}$ & $60.0 \mathrm{a}$ & $62.5 \mathrm{a}$ & $70.7 \mathrm{a}$ \\
\hline $\bar{c}(\%)$ & \multicolumn{5}{|c|}{18.9} \\
\hline Herbicides & \multicolumn{5}{|c|}{$100 \mathrm{DAT}$} \\
\hline Clomazone & $0 \mathrm{a}$ & $9.0 \mathrm{~b}$ & $11.0 \mathrm{a}$ & $13.7 \mathrm{a}$ & $16.3 \mathrm{~b}$ \\
\hline Glyphosate & $0 \mathrm{a}$ & $9.0 \mathrm{~b}$ & $14.0 \mathrm{a}$ & $13.7 \mathrm{a}$ & $16.0 \mathrm{~b}$ \\
\hline Clomazone + glyphosate & $0 \mathrm{a}$ & $17.3 \mathrm{a}$ & $14.3 \mathrm{a}$ & $15.0 \mathrm{a}$ & $25.0 \mathrm{a}$ \\
\hline
\end{tabular}

${ }^{\top}$ Averages followed by the same letter, lowercase in the column - are comparing the herbicide factor within the doses - do not differ by Tukey test $(p \leq 0.05)$. 
The simulated drift of clomazone, glyphosate and the mixture of both presented increases of phytotoxicity of $7.8 ; 6.3$ and $10.8 \%$, respectively, for each $25 \%$ increase in the doses, this, right after their application. This result corroborates to those found by FORESTI et al. (2015) when observing damages in the initial orange trees growth and by GIACOBBO et al. (2018) for the grape crop. The in vivo stability of glyphosate is an important feature that contributes to its irreversible phytotoxic effects (FORESTI et al. 2015). In plants, glyphosate is very stable, with small detectable degradation occurring over a long period of time (DUKE 2011). These are aspects that contribute to maximize the effects caused by drifts.

At 28 DAT the herbicides showed similar effects to those observed in the 14 DAT, but with higher symptoms in relation to the first evaluation in both, sub doses and the recommended dose (Figure 1b). 70, 40 and $35 \%$ phytotoxicity was observed for clomazone + glyphosate, glyphosate and clomazone, respectively, at the recommended dose for the control of $100 \%$ plants (Table 1). These symptoms are elevated because they have compromised the plant growth and development. The $25 \%$ increase of the doses of all the herbicides caused the phytotoxicity increase of 7,$8 ; 9,3$ and $16.8 \%$ for clomazone, glyphosate and the mixture of both, respectively.

At 46 DAT it was found that the clomazone + glyphosate mixture still maintained high phytotoxicity, even by applying sub doses (Figure 1C). It was observed that the injuries caused by the herbicide mixture on the plants were increasing, with $70.7 \%$ phytotoxicity when applying $100 \%$ of the clomazone + glyphosate dose, being this injury greater than that presented by the other treatments when applied in isolation. When exposed to the highest doses of the glyphosate herbicide, pequi plants presented changes in the photosynthetic variables, reducing the gas exchanges characteristics, the photochemical efficiency and the pigment content (SILVA et al. 2016). For clomazone and glyphosate isolated applications, it was observed that $25 \%$ of the recommended dose caused considerable phytotoxicity, $19.3 \%$ for clomazone and $21.7 \%$ for glyphosate, not being statistically different from each other (Table 1). As of the application of $50 \%$ of the dose at 46 DAT, there was a significant difference in herbicide phytotoxicity, with the mixture of glyphosate and clomazone being the most damaging to the lemon tree (Table 1). It should be noted that the producer should be careful when working on aerial sprays with these herbicides, since even in sub doses, they may have similar effects to the recommended doses on lemon tree orchards.

It was observed in the sub-dose $3.13 \%$ of the recommended dose of clomazone + glyphosate, clomazone and glyphosate, phytotoxicity of $10.5 ; 7.1$ and $7.7 \%$, respectively. Thus, it is evident that even if there is a minimal drift of these herbicides in neighboring crops, the applications may compromise the plant growth and development, and consequently fruit production. Results similar to those found in the present study were observed by WAGNER JR. et al. (2008) when simulating glyphosate drift in yellow passion fruit. These authors concluded that the herbicide caused a reduction in the growth and development of passion fruit plants.

Despite phytotoxicity decreased to 100 DAT (Figure 1D), with maximum rates observed for the clomazone + glyphosate mixture approaching $20 \%$, and $10 \%$ for isolated applications at all doses applied, it was found that the new shoots emerged atrophied, due the herbicides were still causing effects on the plants. There was herbicides variation only in the dose of $100 \%$, in which again the mixture of glyphosate and clomazone was the most harmful to the culture (Table 1). The clomazone drift caused leaf abscission, leaf mortality, chlorosis, chlorotic and necrotic spots on fruit peels (TIMOSSI \& ALVES 2001). FORESTI et al. (2015) reported the occurrence of leaf area decrease, chlorophyll content, leaf dry mass and orange tree stem after the occurrence of clomazone drift.

There was an interaction between the different treatments only for the increment of the trunk diameter at the grafting point, where the different doses when compared between the different herbicides interfered in the increase of the trunk diameter only in the dose $25 \%$ of the recommended one, whose mixture of clomazone with glyphosate was the most detrimental to the trunk diameter increase and pure clomazone the least harmful. When evaluating the herbicides with the different doses, it was verified that only glyphosate showed differences, and the use of $25 \%$ of the recommended dose presented a greater increase of the trunk diameter at the grafting point of the plants than when compared to the maximum dose, in which it presented the smallest increase of the trunk diameter at the grafting point (Table 2).

The fruit species may have different behavior in relation to stem diameter, since in passion fruit plants no effects were found in this variable, due to simulated drift of different formulations and doses of glyphosate herbicide (WAGNER JR. et al. 2008). When comparing the herbicides with each other, only $25 \%$ of the recommended dose showed some difference, where the plants with clomazone presented higher trunk diameters at the grafting point, differing only from the clomazone + glyphosate mixture. Simulating glyphosate drift in Jatropha curcas plants COSTA et al. (2009) the results showed that the diameter of the 
stem showed greater losses in the doses of 180 and $360 \mathrm{~g} \mathrm{ha}^{-1}$ of glyphosate, with an average of 10.8 and $31,5 \%$ lower, respectively, than the control without application. In the case of passion fruit plants, the simulated glyphosate drift did not affect the stem diameter of the plants (WAGNER JR. et al. 2008), the same result as in the present experiment.

Table 2. Increase of the trunk diameter at the grafting point in lemon cv. BRS-Fine, depending on the recommended dose of the herbicide for agricultural crops application.

\begin{tabular}{ccccc}
\hline Herbicides doses (\%) & Clomazone & Glyphosate & $\begin{array}{c}\text { Clomazone }+ \\
\text { glyphosate }\end{array}$ & Average \\
\hline 0 & $47.79 \mathrm{aA}{ }^{*}$ & $47.79 \mathrm{abA}$ & $47.79 \mathrm{aA}$ & $47.79 \mathrm{a}$ \\
25 & $91.00 \mathrm{aA}$ & $86.28 \mathrm{aAB}$ & $49.16 \mathrm{aB}$ & $75.48 \mathrm{a}$ \\
50 & $82.96 \mathrm{aA}$ & $64.41 \mathrm{abA}$ & $52.53 \mathrm{aA}$ & $66.63 \mathrm{a}$ \\
75 & $56.01 \mathrm{aA}$ & $67.05 \mathrm{abA}$ & $60.74 \mathrm{aA}$ & $61.27 \mathrm{a}$ \\
100 & $65.77 \mathrm{aA}$ & $31.24 \mathrm{bA}$ & $54.35 \mathrm{aA}$ & $50.45 \mathrm{a}$ \\
\hline Average & $68.71 \mathrm{~A}$ & $59.36 \mathrm{~A}$ & $52.92 \mathrm{~A}$ & \\
\hline CV $(\%)$ & \multicolumn{5}{c}{24.7} \\
\hline${ }^{*}$ Different, lowercase letters in the column and uppercase in the row, differ by Duncan's test $(\mathrm{p} \leq 0,05)$.
\end{tabular}

To increase the rootstock diameter, differences were observed only for the use of herbicide doses, with no differences between herbicides (Figure 2A). The model that fitted in this variable was an hyperbolic equation, in which with the increase of the herbicide dose, there was a slight increase in the diameter of the trunk of the rootstock and later stabilization occurred, even increasing of the percentage of the applied dose. Differences were not observed for the trunk graft.

In increasing plant height it was observed statistical differences only when comparing the factors separately. It is noticed that there was a reduction with the increase of the herbicide dose, while at dose 0 the height increased $26.91 \%$, at $25,50,75$ and $100 \%$ of the commercial dose the height increase was 24.18 ; $21.45 ; 18.72$ and $15.99 \%$, respectively (Figure $2 \mathrm{~A}$ ). Figure 2B shows that the herbicide glyphosate applied in isolation was more harmful than clomazone, but did not differ from the mixture of both. In this way it is clear the negative effect of the herbicides and of the different doses, simulating drift on the lemon tree plants.
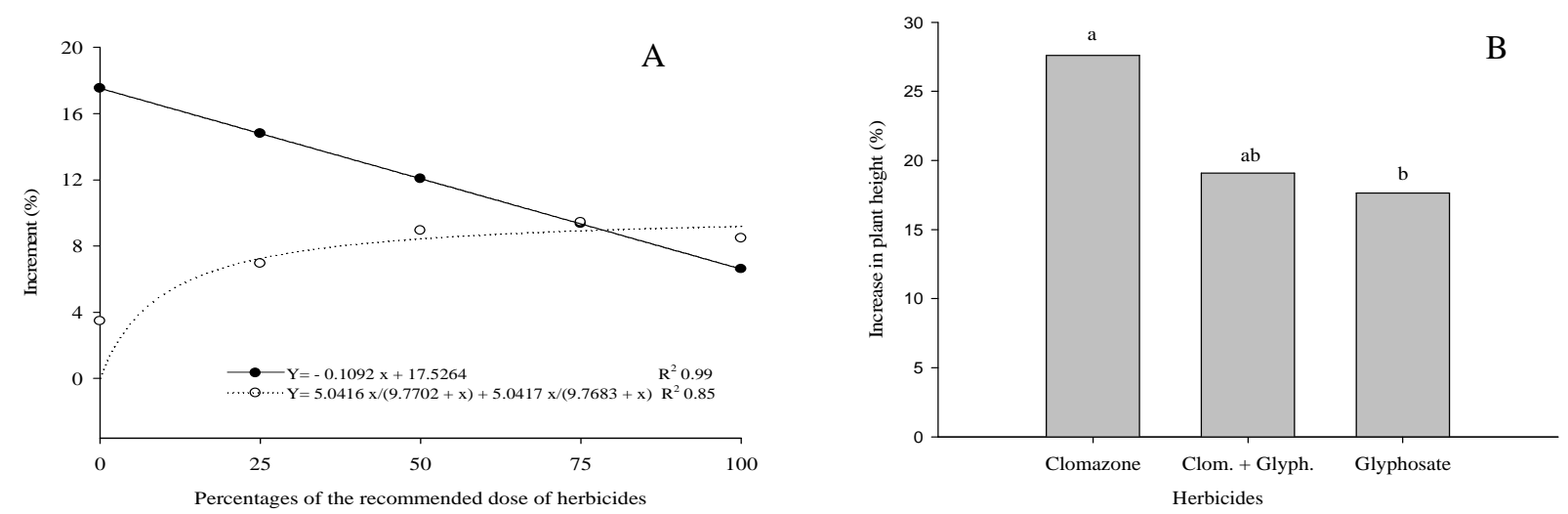

Figure 2. Increase in plant height $(\bullet)$ and increment of stem diameter $(\circ)$ due to the herbicide dose $(A)$ and increase in plant height due to the herbicides (B), simulating drift.

It was observed a higher phytotoxicity with the mixture of both herbicides (Figure 1 and Table 1), but the response of the increment of plant height was smaller in the glyphosate application. Studying the effect of accidental applications (drift) of glyphosate herbicide in Citrus limonea (Rangpur lime) seedlings. GRAVENA et al. (2009) found no huge visual effects in plants, just transient effects on the free amino acid content, shikimate and totals, and the tested doses were $0,180,360$ and $720 \mathrm{~g} \mathrm{ha}^{-1}$ of ea, and establishing connection with the present experiment, in which the visual symptoms did not match with the variable increment of plant height.

Whereas, for the variable increment of crown volume, according to the obtained results, no significant differences were observed in the percentage of increment between the different herbicides and doses, with average of $8.19 \%$. Valencia orange plants grafted on 'Clove' lemon and 'Swingle' citrumelo showed no injuries after glyphosate applications on the stem, but when the application was done on the plants crown at 
a dose greater than $360 \mathrm{~g} \mathrm{ha}^{-1}$ of and the main symptoms were observed in the growth meristems (GRAVENA et al. 2012). These meristems are responsible for the canopy formation, damaging the plants development, as observed by COSTA et al. (2009), where the increased glyphosate herbicide dose simulating drift, decreased the crown volume of Jatropha.

As the $\mathrm{CO}_{2}$ net assimilation at 10 DAT it was observed that only the control treatment performed gas exchanges. In contrast, at 60 DAT, it was observed that at doses 25,50 and $75 \%$ of the recommended, the sprinkled plants with clomazone presented higher $\mathrm{CO}_{2}$ net assimilation than those with glyphosate and clomazone + glyphosate; and for $100 \%$ of the recommended dose, clomazone and glyphosate were highlighted from the combination clomazone + glyphosate (Table 3). Less $\mathrm{CO}_{2}$ net assimilation to clomazone + glyphosate, corroborates with that observed for the phytotoxicity characteristic, where the combination showed more pronounced drift effects in the plants than the isolated spraying of clomazone and glyphosate. Like greater phytotoxicity, lower $\mathrm{CO}_{2}$ net assimilation reflects herbicide-induced damage to plants.

Table 3. $\mathrm{CO}_{2}$ Net assimilation ( $\mu \mathrm{mol} \mathrm{CO}_{2} \mathrm{~m}^{-2} \mathrm{~s}^{-1}$ ) in BRS-Fino Lemon cultivar at 60 days after application of the percentages of the recommended herbicide dose used to control weeds in irrigated rice.

\begin{tabular}{lcccccc}
\hline \multirow{2}{*}{ Herbicides } & \multicolumn{7}{c}{ Percentages of the recommended dose of herbicides } \\
\cline { 2 - 7 } & 0 & 25 & 50 & 75 & 100 & Média \\
\hline Clomazone & $8.8 \mathrm{a}^{1}$ & $13.2 \mathrm{a}$ & $12.4 \mathrm{a}$ & $8.1 \mathrm{a}$ & $5.7 \mathrm{a}$ & 9.7 \\
Glyphosate & $8.8 \mathrm{a}$ & $10.9 \mathrm{~b}$ & $8.8 \mathrm{~b}$ & $5.4 \mathrm{~b}$ & $5.1 \mathrm{a}$ & 7.9 \\
Clomazone+ glyphsate & $8.8 \mathrm{a}$ & $5.2 \mathrm{c}$ & $3.9 \mathrm{c}$ & $3.7 \mathrm{c}$ & $1.1 \mathrm{c}$ & 4.6 \\
\hline Averages & 8.8 & 9.8 & 8.4 & 5.7 & 4.0 & -- \\
\hline C.V. $(\%)$ & \multicolumn{7}{c}{15.2} \\
\hline
\end{tabular}

Different, lower-case letters in the column, differ by Tukey's test $(p \leq 0.05)$.

At 60 DAT, the lemon trees sprayed with 25 and $50 \%$ of the recommended dose of clomazone and $25 \%$ of the dose of glyphosate, stood out when compared to the other doses, with quadratic adjustments of the regression equation. For the application of clomazone + glyphosate mixture, there was a decreasing linear adjustment of the equation, with the control dose $(0 \%$ of the recommended dose) presenting the highest $\mathrm{CO}_{2}$ net assimilation (Figure 3).

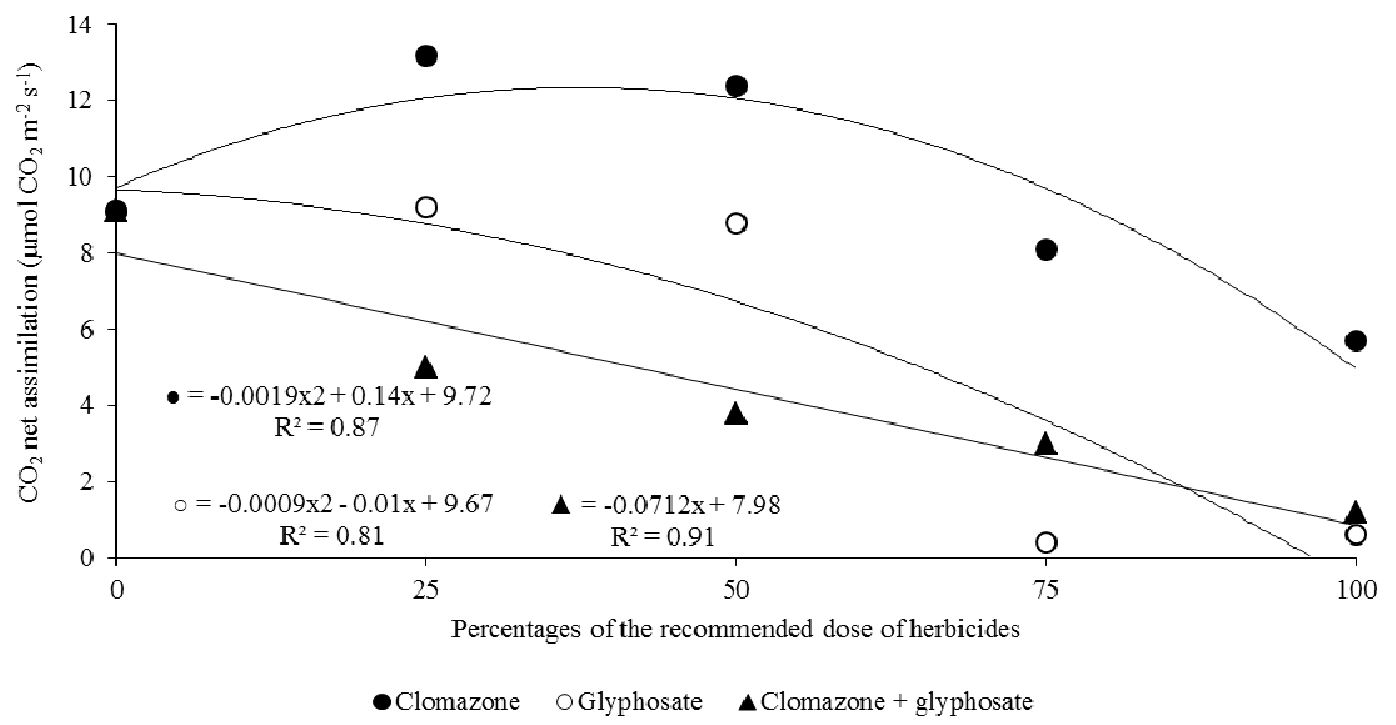

Figure 3. $\mathrm{CO}_{2}$ net assimilation (Mmol $\mathrm{CO}_{2} \mathrm{~m}^{-2} \mathrm{~s}^{-1}$ ) in BRS-Fine, Lemon tree plants at 60 days after application of the percentages of $0,25,50,70$ and $100 \%$ in relation to the recommended dose of clomazone $(\bullet)$, glyphosate $(\circ)$, and the clomazone + glyphosate $(\mathbf{\Delta})$ tank mix.

Quadratic adjustment of the regression equation for isolated sprays of clomazone and glyphosate, possibly due to the plants that survived the application of clomazone and glyphosate at lower than recommended doses, are assimilating more $\mathrm{CO}_{2}$ to repair damage caused by herbicides (GIACOBBO et al. 2018). In the case of clomazone that acts to eliminate the precursor to carotenoids, low concentrations of herbicides can stimulate plants to produce new compounds without promoting excessive damage (RIBEIRO et al. 2020). The tendency is that, during the recovery process of certain stress, plants present superior 
photosynthetic yield, aiming to obtain the maximum possible assimilates that will be synthesized in the repair of damaged tissues and emission of new vegetative structures. In contrast, when referring to the combination clomazone + glyphosate, possibly due to the drift damage in the plants being even more in-depth, those at 60 DAT, showed a significant reduction of the $\mathrm{CO}_{2}$ net assimilation.

At 60 DAT, the lemon trees sprayed with 25 and $50 \%$ of the recommended dose of clomazone and $25 \%$ of the dose of glyphosate, stood out when compared to the other doses, with quadratic adjustments of the regression equation. For the application of the clomazone + glyphosate mixture, there was a linearly decreasing linear adjustment of the equation, with the control dose $(0 \%$ of the recommended dose) presenting the highest net $\mathrm{CO}_{2}$ assimilation (Figure 3). Although gas exchange rates were zero at 10 DAT for any herbicide application, greater $\mathrm{CO}_{2}$ net assimilation at 60 DAT for clomazone and glyphosate compared to their combined application demonstrates that the isolated application of these herbicides enabled a faster recovery of the plants.

The tank mixture of clomazone + glyphosate at all tested doses showed the highest phytotoxicity and the lowest $\mathrm{CO}_{2}$ net assimilation on lemon tree. The doses 75 or $100 \%$ of the recommended clomazone, glyphosate or the mixture of both to simulate the drift, caused the fall of the leaves, occurrence of abnormal shoots, with new atrophied leaves. The herbicides and the increase of these doses caused a negative effect on the lemon tree plant height. Herbicides and doses have no influence on the increment of trunk of rootstock, graft and grafting point and crown volume.

\section{CONCLUSION}

The tank mixture of clomazone + glyphosate in all tested doses was the one that presented the highest phytotoxicity and the lowest net $\mathrm{CO}_{2}$ assimilation on the lemon tree.

The doses of 75 or $100 \%$ of recommended clomazone, glyphosate or the mixture of both to simulate the drift, caused the leaves to fall, abnormal shoots to occur, with new stunted leaves.

Herbicides and increased doses of these caused a negative effect on the height of lemon trees.

Herbicides and doses have no influence on increasing rootstock stem, graft and grafting point and crown volume.

\section{ACKNOWLEDGEMENTS}

To the CNPq, to the FAPERGS and to the FINEP by the financial assistance to the research and by the concessions of scholarships.

\section{REFERENCES}

BANDANA B et al. 2015. Dissipation kinetics of glyphosate in tea and tea-field under northwestern mid-hill conditions of India. Journal of Pesticide Science 40: 82-86.

CABRAL CM et al. 2017. Tolerance to the herbicide clomazone and potential for changes of forest species. Bioscience Journal 33: 897-904.

COSTA AGF et al. 2007. Effect of wind intensity, pressure and nozzles on spray drift from pre-emergence herbicide applications. Planta Daninha 25: 203-210.

COSTA NV et al. 2009. Effect of simulated glyphosate drift on the initial growth of physic nut plants. Planta Daninha 27: 1105-1110.

CUNHA JPAR. 2008. Pesticide drift simulation under different spray conditions. Ciência e Agrotecnologia 32: 1612-1621.

DRIVER KE et al. 2020. Mechanism of clomazone resistance in Leptochloa fusca spp. fasicularis to clomazone.

Pesticide Biochemistry and Physiology 162: 1-5.

DUKE SO. 2018. The history and current status of glyphosate. Pest Management Science 74: 1027-1034.

DUKE SO. 2011. Glyphosate degradation in glyphosate-resistant and susceptible crops and weeds. Journal of Agricultural and Food Chemistry 59: 5835-5841.

EGAN JF et al. 2014. Herbicide drift can affect plant and arthropod communities. Agriculture, Ecosystems and Environment 185: 77-87.

FERREIRA FB et al. 2006. Consequences of simulated drift of herbicide glyphosate in flooded rice (Oryza sativa L.). Revista Brasileira de Agrociência 12: 309-312.

FORESTI ER et al. 2015. Simulação da deriva de clomazone e glyphosate em mudas de laranjeira 'Hamlin'. Revista Brasileira de Fruticultura 37: 367-376.

FOROUZESH A et al. 2015. Classification of herbicides according to chemical family for weed resistance management strategies-an update. Weed Research 55: 334-358.

GANDOLFO MA et al. 2012. Potential for drifting of mix 2,4-D + glyphosate. Revista Brasileira de Herbicida 11: 332-338.

GIACOBBO CL et al. 2018. Simulated drift of herbicides applied alone and in tank mix in grapevine. Communications in Plant Sciences 8: 22-30. 
GRAVENA R et al. 2012. Glyphosate has low toxicity to citrus plants growing in the field. Canadian Journal of Plant Science 92: 119-127.

GRAVENA R et al. 2009. Low glyphosate rates do not affect Citrus limonia (L.) Osbeck seedlings. Pest Management Science 65: 420-425.

HEMPHILL DD \& MONTGOMERY ML. 1981. Response of vegetable crops to sublethal application of 2,4-D. Weed Science 29: 632-635.

IBGE. 2019. Instituto Brasileiro de Geografia e Estatística. Sistema IBGE de Recuperação Automática - SINDRA. Disponível em: <http://www.sidra.ibge.gov.br/bda/tabela/protabl.asp?>. Acesso em: 16 dez. 2019.

MOHAPATRA S et al. 2017. Efficacy of pre-emergence herbicides for control of complex weed flora in transplanted rice. Indian Journal of Weed Science 49: 216-218.

OLIVEIRA RB et al. 2013. Potential of adjuvants to reduce drift in agricultural spraying. Engenharia Agrícola 34: $986-992$.

OLIVEIRA JR. RS. 2011. Mecanismo de ação de herbicidas. In: OLIVEIRA JR. RS et al. Biologia e manejo de plantas daninhas. Curitiba: Omnipax. p.141-192.

RIBEIRO VHV et al. 2020. Morphoanatomical injuries in Pistia stratiotes L. (Araceae) as a result of exposure to clomazone in water. Anais da Academia Brasileira de Ciências 92: 1-15.

RIGOLI RP et al. 2008. Response of beetroot (Beta vulgaris) and carrot (Daucus carota) to simulated glyphosate and clomazone drift. Planta daninha 26: 451-456.

RODRIGUES BN \& ALMEIDA FS. 2018. Guia de herbicidas. 7.ed. Londrina: Edição dos autores. 764p.

RODRIGUES EB et al. 2015. Drift of glyphosate application using backpack sprayers. Revista Brasileira de Engenharia Agrícola e Ambiental 19: 1012-1017.

RONCHI CP et al. 2005. Effect of 2,4- dichlorophenoxyacetic acid applied as a herbicide on fruit shedding and coffee yield. Weed Research 45: 41-47.

SANTOS HG et al. 2013. Sistema Brasileiro de Classificação de Solos. 3.ed. Brasília: Embrapa. 353p.

SILVA LQ et al. 2016. Modificações fisiológicas em folhas de pequi (Caryocar brasiliense) causadas pela aplicação de glyphosate. Revista Brasileira de Herbicidas 15: 184-194.

SILVA MM et al. 2018. Intoxication and physiological aspects of forage plants and weeds submitted to clomazone atmospheric waste. Planta daninha 36: 1-11.

SBCPD. 1995. Sociedade Brasileira da Ciência das Plantas Daninhas. Procedimentos para instalação, avaliação e análise de experimentos com herbicidas. Londrina: SBCPD. 42p.

TIMOSSI PC \& ALVES PLCA. 2001. Effects of clomazone drift, sprayed alone or in mixture with ametryn, on the productive characteristics of hamlin orange. Planta Daninha 19: 295-304.

WAGNER JR. A et al. 2008. Drift Simulation of glyphosate commercial formulations on yellow passion fruit growth. Planta Daninha 26: 677-683. 